\title{
Molecular Identification of Equine Herpesvirus I, 2, and 5 in Equids with Signs of Respiratory Disease in Central Ethiopia
}

\author{
Tuge Temesgen' \\ Yitbarek Getachew ${ }^{2}$ \\ Haileleul Negussie ${ }^{2}$ \\ 'College of Agriculture and Natural \\ Resource, Asossa University, Asossa, \\ Ethiopia; ${ }^{2}$ Department of Clinical \\ Medicine, College of Veterinary Medicine \\ and Agriculture, Addis Ababa University, \\ Bishoftu, Ethiopia
}

Background: Equine herpesvirus (EHV) infections have major economic, health, and welfare impacts on equids. This study was performed in three selected zones of central Ethiopia with the objectives of detecting EHV-1, -2, and -5 in horses and donkeys with suggestive signs of respiratory tract disease and to assess epidemiological risk factors associated with infections.

Methods: A total of 58 nasopharyngeal swab samples were collected from donkeys and horses showing clinical signs of respiratory disease. Polymerase chain reaction (PCR) was used to detect EHV-1, -2 , and -5 . Evaluation of the associated risk factors was conducted using a multivariable logistic regression model.

Results: Among the 58 equids tested, 36 (62\%), 31 (53\%), and 15 (25\%) equids were positive for EHV-1, -2, and -5, respectively. Concurrent infections with EHV-1 and EHV-2 (31\%), EHV-1 and EHV-5 (17\%), EHV-2 and EHV-5 (15.5\%), and EHV-1, -2, and -5 (13\%) were recorded. EHV-1 was detected significantly in higher proportion in donkeys $(76 \% ; 95 \%$ CI: 1.066-2.251; P = 0.047) compared with horses (51.5\%). In contrast, horses had fourteen times more likely to be positive for EHV-2 (OR: 13.66; 95\% CI: 3.119-59.816; P = 0.001) compared to donkeys. Detection of EHV-1, -2, and -5 was no significant association with age, sex, and body condition score.

Conclusion: The present study revealed the molecular evidence of EHV-1, -2, and -5 infection in donkeys and horses with signs of respiratory disease. It also documented that donkeys and horses have varying levels of susceptibility to EHVs. This species-specific in susceptibility difference to EHVs infections should be further elucidated.

Keywords: equids, equine herpesviruses, epidemiology, PCR, Ethiopia

\section{Introduction}

Working equids have a great significance in the development of Ethiopia, where they have an essential role in reducing poverty, providing food security, and enhancing rural development. ${ }^{1}$ These animals are especially important to vulnerable groups, landless communities, and to women, where they can provide an effective entry point to income-generating activities. Numerous infectious diseases negatively impact the health and productivity of working equids. Respiratory viral diseases have been identified as one of the major health threats to equids, which cause significant economic losses. ${ }^{2,3}$ Respiratory diseases are consistently ranked amongst the top three health problems of the equids in Ethiopia. ${ }^{4}$ Many viral agents have been associated with respiratory disease of equids, although the level of
Correspondence: Haileleul Negussie Department of Clinical Medicine, College of Veterinary Medicine and Agriculture, Addis Ababa University, P. O. Box: 34, Bishoftu, Ethiopia

Email haileleul.negussie@aau.edu.et 
evidence of causation for some of these agents is tenuous. Equine herpesviruses (EHVs) have major economic and welfare impacts on the equine industry worldwide. Despite their importance, studies on the epidemiology of these respiratory viruses in Ethiopian working equids are limited. Thus, understanding the distribution of these viral diseases is helpful to implement appropriate control strategies.

EHV-1 belonging to the subfamily Alphaherpesvirinae is one of the most important and prevalent viral pathogens in equids and a major threat to the equine industry throughout the world. ${ }^{5}$ EHV-1 infection may induce several clinical forms of disease including respiratory infection associated with pyrexia, cough, and respiratory distress. ${ }^{3}$ The virus may spread to distant organs enables the development of more severe sequelae such as abortion in pregnant mares, stillbirth and neonatal death, and neurological disorders including Equine Herpesvirus Encephalomyelitis. ${ }^{3,6}$ However, the severity of the disease resulting from EHV-1 infection is likely to be influenced by several factors, including the age and physical condition of the host, whether the infection is primary, secondary, or a reactivation of a latent virus, the immune status of the host and the virulence of the strain involved. ${ }^{7}$

Equine herpesvirus $2(\mathrm{EHV}-2)$ and equine herpesvirus 5 (EHV-5) belong to the Gammaherpesvirinae subfamily, which has been detected in equids worldwide. ${ }^{2}$ These viruses typically cause upper respiratory tract disease (eg pharyngitis), ${ }^{8,9}$ or keratoconjunctivitis ${ }^{10,11}$ accompanied by clinical signs such as nasal and ocular discharge, tachypnea, coughing, fever, enlarged lymph nodes, anorexia, poor body condition, and depression. EHV-5 is commonly associated with fatal equine multinodular pulmonary fibrosis. ${ }^{12,13}$

The epidemiological features associated with EHVs in equids are a high incidence of respiratory infection early in life, the establishment of lifelong latency, and reactivation of latent virus with subsequent shedding. ${ }^{5,14,15}$ Latently infected equids experience reactivation episodes, during which infectious virus shed into respiratory tract secretions, resulting in transmission to naive hosts. ${ }^{16}$ The physiological factors responsible for the activation of the latent virus are associated with stressors including weaning, commingling, transportation, and concurrent infections. $^{3}$

Infectious diseases compromise the health and welfare of working equids, which in turn threatens the livelihoods of the most vulnerable members of society. ${ }^{1}$ EHVs are among the infectious viral diseases that have a significant socio-economic impact on the equine industry. Previous studies have documented that respiratory disease particularly coughing and nasal discharge, is one of the major health concerns for working equids in Ethiopia. ${ }^{4}$ Equine herpesviruses are important pathogens that are involved in the respiratory disease of varying severity and an important cause of serious morbidity and mortality in Ethiopian equids. ${ }^{17,18}$ Despite their importance, information regarding the epidemiology of EHVs associated with outbreaks of respiratory disease in working equids in Ethiopia is limited. Thus, investigation of EHVs and associated determinants in clinically respiratory diseased equids in different regions of the country would be a valuable input to the current understanding of EHVs epidemiology in the different geographical settings and unvaccinated equine populations. Understanding the risk factors that contribute to the development and/or distribution of these viral diseases is also helpful to develop appropriate control strategies. Therefore, the present study was conducted with the objectives of identifying EHV-1, -2, and -5 from horses and donkeys with suggestive signs of respiratory tract disease and assessing the risk factors associated with infections.

\section{Materials and Methods Study Area}

This study was conducted in three selected zones such as the North Shewa, East Shewa, and West Arsi zones as shown in Figure 1. In the North Shewa zones of Amhara Regional State, three districts were selected for sampling such as Angolela Tera, Kembibit, and Debre Berhan Zuria, whereas from East Shewa and West Arsi zones of Oromia Regional State Ada'a and Arsi Negele districts, respectively, were included for this study.

\section{Study Population and Study Design}

Investigation of equine respiratory disease outbreaks in equids was performed in selected districts of the study sites. The study population comprised all ages of horses and donkeys with respiratory clinical signs such as unexplained fever (rectal temperature $\geq 38{ }^{\circ} \mathrm{C}$ for donkeys and $\geq 38.5{ }^{\circ} \mathrm{C}$ for horses), depression, nasal discharge, and coughing. Nasopharyngeal swabs were collected with viral transport medium (VTM) containing 


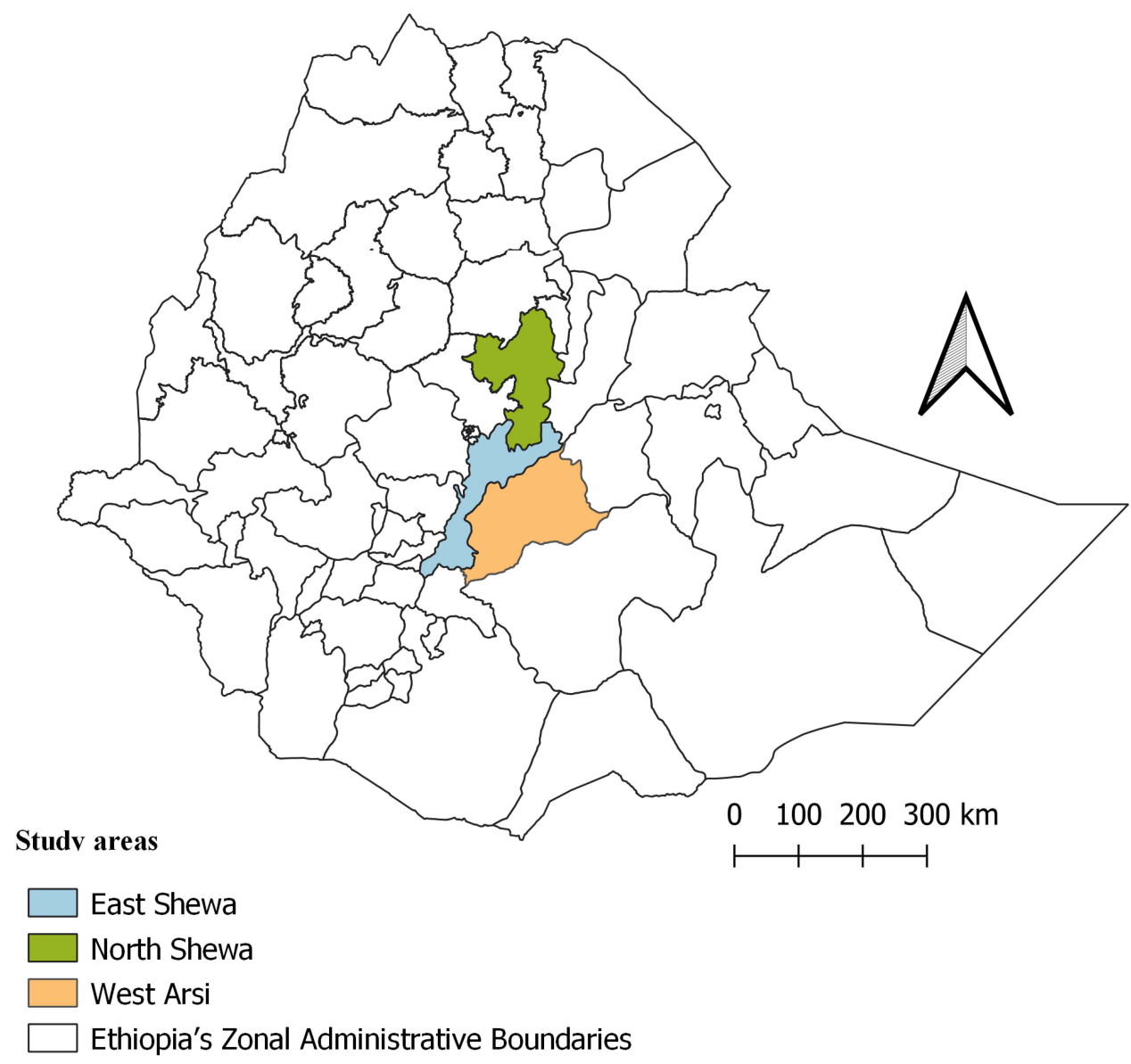

Figure I Map of Ethiopia illustrating the study areas. This map was developed from Ethiopian's Zonal Administrative boundaries shape file 202I using QGIS version 3.I.I.2.

an equal amount of glycerol and $0.04 \mathrm{M}$ of phosphatebuffered saline (PBS) supplemented with $1 \mu \mathrm{g} / \mathrm{mL}$ gentamycin (Invitrogen, Paisley, UK), $1 \mathrm{mg} / \mathrm{mL}$ streptomycin (Certa, Braine l'Alleud, Belgium), $1 \mathrm{mg} / \mathrm{mL}$ kanamycin (Sigma, St. Louis, MO, USA), 1000 U/mL penicillin (Continental Pharma, Puurs, Belgium) and 5 $\mu \mathrm{g} / \mathrm{mL}$ amphotericin B (Bristol-Myers Squibb, New York, USA). From equids with signs of respiratory disease, a total of 58 nasopharyngeal swabs were collected using sterile cotton swabs and kept in tubes containing $2 \mathrm{~mL}$ of VTM. All samples were immediately placed in a cool box and transported under a cold chain to the National Veterinary Institute (NVI) Ethiopia for testing. During sampling, information such as species, sex, age, and body condition score of the sampled animals was recorded. The age of the animals was variable ranged from 6 months to 14 years. The age was categorized as $\leq 4$ years (young), 5-9 years (adult), and $\geq 10$ years (old) as previously described by Cozzi et al ${ }^{19}$ with some modification. The body condition of the animals was also scored as poor, medium, and good body condition according to Henneke et al. ${ }^{20}$

\section{DNA Extraction and Thermal Amplification}

The total DNA was extracted from $200 \mu \mathrm{L}$ of nasopharyngeal swabs using a DNeasy Blood and Tissue Kit (Qiagen) according to the manufacturer's instructions with a final DNA elution volume of $50 \mu \mathrm{L}$.

Primers that are specific to EHV-1, ${ }^{21} \mathrm{EHV}-2,{ }^{22}$ and EHV $-5^{23}$ were employed for PCR thermal amplification as shown in Table 1. PCR amplification was performed using virus-specific primers for the detection of EHV-1, -2 , and -5. DNA amplification was carried out in a total volume of 25 $\mu \mathrm{L}$ PCR reaction mixtures. Each of the $25 \mu \mathrm{L}$ PCR mixtures contained $12.5 \mu \mathrm{L}$ of nuclease-free water, $5 \mu \mathrm{L}$ of 5 $\mathrm{x}$ Herculase II reaction buffer, $0.5 \mu \mathrm{L}$ Herculase II fusion DNA polymerase, $0.5 \mu \mathrm{L}$ of $25 \mathrm{mM}$ each deoxynucleoside triphosphate (dNTP) mix, $1 \mu \mathrm{L}$ of each forward and reverse primers, $2.5 \mu \mathrm{L}$ of dimethyl sulphoxide (DMSO), and $2 \mu \mathrm{L}$ 
Table I Primers Used for Amplification of Specific Regions of the Genome of EHV-I, -2, and -5

\begin{tabular}{|l|l|l|l|}
\hline Virus & Target & Oligonucleotides & Size \\
\hline EHV-I & ORF30 & $\begin{array}{l}\text { FW: 5'GCTACTTCTGAAAACGGAGGC-3' } \\
\text { RV: 5'-TATCCTCAGACACG GCAACA-3' }\end{array}$ & 466 bp \\
\hline EHV-2 & gB & $\begin{array}{l}\text { FW: 5'-GCCAGTGTCTGCCAAGTTGATA-3' } \\
\text { RV: 5'ATACGATCACATCCAATCCC-3' }\end{array}$ & 444 bp \\
\hline EHV-5 & gB & $\begin{array}{l}\text { FW: 5' ATGAACCTGACAGATGTGCC 3' } \\
\text { RV: 5' CACGTTCACTATCACGTCGC 3' }\end{array}$ & 293 bp \\
\hline
\end{tabular}

Abbreviations: FW, forward; RV, reverse.

template DNA. In each reaction, a negative control (nuclease-free water) was included. The region of interest of ORF30 was amplified with an initial denaturation step of $95^{\circ} \mathrm{C}$ for $15 \mathrm{~min}$, followed by 34 cycles of denaturation at $94^{\circ} \mathrm{C}$ for $1 \mathrm{~min}$, annealing at $55.5^{\circ} \mathrm{C}$ for $1 \mathrm{~min}$, extension at $72^{\circ} \mathrm{C}$ for $1 \mathrm{~min}$, and a final extension at $72^{\circ} \mathrm{C}$ for $10 \mathrm{~min}$. The PCR assay targeting the gB genes of EHV-2 and EHV-5 was amplified using the following thermocycling conditions: an initial denaturation step of $95^{\circ} \mathrm{C}$ for $5 \mathrm{~min}$, followed by 40 cycles of amplification, using denaturation at $95^{\circ} \mathrm{C}$ for 30 $\mathrm{s}$, annealing at $60^{\circ} \mathrm{C}$, and extension at $72^{\circ} \mathrm{C}$ for $45 \mathrm{~s}$ and followed by a final extension at $72{ }^{\circ} \mathrm{C}$ for $10 \mathrm{~min}$.

The positive PCR products were identified based on amplified band size on a $1.5 \%$ agarose gel. The band sizes of $466 \mathrm{bp}, 444 \mathrm{bp}$, and $293 \mathrm{bp}$ are specific to EHV-1, EHV-2, and EHV-5, respectively (Figure 2).

\section{Statistical Analysis}

Data were organized in Microsoft Excel 2010 spreadsheets and analyzed using the STATA version 13 for Windows (Stata Corp. College Station, TX, USA). The strength of the association between outcome and explanatory variables was assessed by using the odds ratio (OR).
Multivariable logistic regression analyses were used to model the effects of potential risk factors on the outcome variables. The effects of risk factors were considered statistically significant when P-value was less than 0.05 .

\section{Results}

In this study, among the 58 equids tested, 36 (62\%), 31 (53\%), and $15(25 \%)$ equids were positive for EHV-1, -2, and -5 , respectively (Table 2). EHV-1 was detected at the highest proportion (62\%), of which $75 \%$ were from donkeys and $51.52 \%$ were from horses, followed by EHV-2 (53\%), of which $24 \%$ were from donkeys and $75.76 \%$ were from horses. EHV-5 was detected with the lowest proportion (25\%), of which $28 \%$ were from donkeys and $24.2 \%$ were from horses. Concurrent infections with EHV-1 and EHV-2 (31\%), EHV-1 and EHV-5 (17\%), EHV-2 and EHV-5 (15.5\%), and EHV-1, -2, and -5 (13.8\%) were recorded.

The current study revealed that significantly $(\mathrm{P}=0.047)$ higher proportion of EHV-1 was detected in donkeys (76\%; 95\% CI: 1.066-2.251) compared with horses (51.5\%) (Table 3). In contrast, the occurrence of EHV-2 was statistically $(\mathrm{P}=0.001)$ higher in horses $(75.8 \%$; 95\% CI: 3.119 $59.816)$ compared with donkeys (24\%) (Table 4). Although
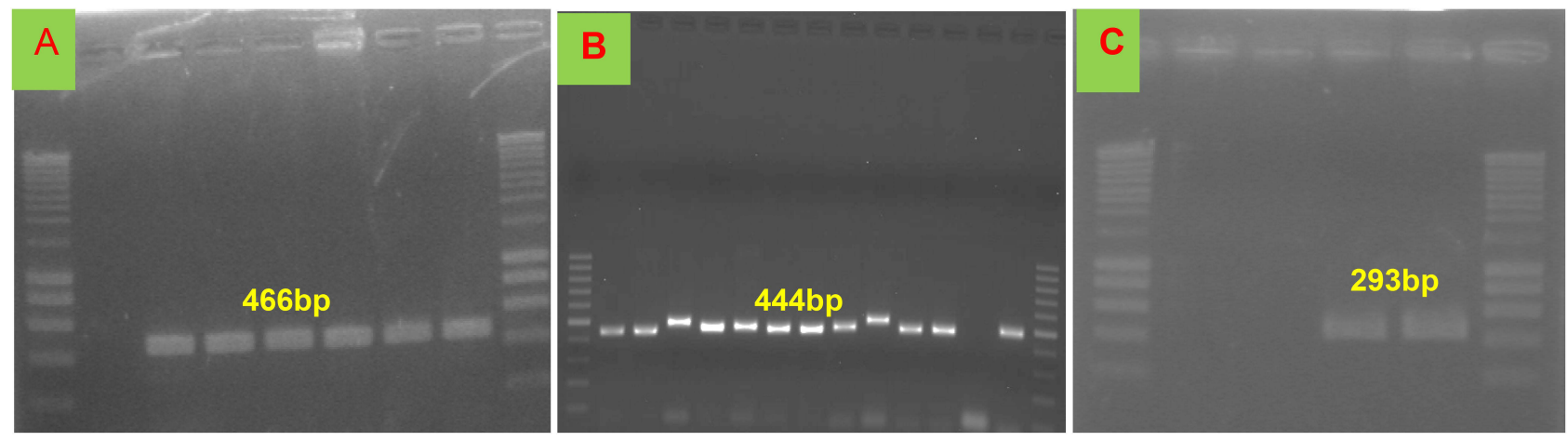

Figure 2 Representative agarose gel electrophoresis of DNA-amplified product generated by targeting specific regions of ORF30 EHV-I (466 bP) (A) on I.5\% agarose gel with a DNA Molecular Weight Marker (MWM) of 200 bp, and EHV-2 gpB gene (444 bp) (B) and EHV-5 gpB gene (293 bp) (C) on I.5\% agarose gel with a DNA Molecular Weight Marker of $100 \mathrm{bp}$. 
Table 2 The Proportion of Equids That are Positive for EHV-I, -2 , and -5 from Donkeys and Horses with Signs of Respiratory Diseases

\begin{tabular}{|c|c|c|c|c|}
\hline Risk Factors & $\begin{array}{l}\text { No. of } \\
\text { Equids }\end{array}$ & $\begin{array}{l}\text { EHV-I } \\
\text { Positive (\%) }\end{array}$ & $\begin{array}{l}\text { EHV-2 } \\
\text { Positive (\%) }\end{array}$ & $\begin{array}{l}\text { EHV-5 } \\
\text { Positive (\%) }\end{array}$ \\
\hline $\begin{array}{l}\text { Species } \\
\text { Donkeys } \\
\text { Horses }\end{array}$ & $\begin{array}{l}25 \\
33\end{array}$ & $\begin{array}{l}19(76) \\
17(51.5)\end{array}$ & $\begin{array}{l}6(24) \\
25(75.8)\end{array}$ & $\begin{array}{l}7(28) \\
8(24.2)\end{array}$ \\
\hline $\begin{array}{l}\text { Sex } \\
\qquad \text { Male } \\
\text { Female }\end{array}$ & $\begin{array}{l}32 \\
26\end{array}$ & $\begin{array}{l}17(53.1) \\
19(73.1)\end{array}$ & $\begin{array}{l}21(65.6) \\
10(38.5)\end{array}$ & $\begin{array}{l}9(28.1) \\
6(23.1)\end{array}$ \\
\hline $\begin{array}{l}\text { Age } \\
\qquad 4 \text { years } \\
5-9 \text { years } \\
\geq 10 \text { years }\end{array}$ & $\begin{array}{l}24 \\
25 \\
9\end{array}$ & $\begin{array}{l}\text { I5 (62.5) } \\
\text { I5 (60) } \\
6(66.7)\end{array}$ & $\begin{array}{l}14(58.3) \\
13(52) \\
4(44.4)\end{array}$ & $\begin{array}{l}7(29.2) \\
6(24) \\
2(22.2)\end{array}$ \\
\hline $\begin{array}{l}\text { Body condition } \\
\text { score } \\
\text { Poor } \\
\text { Medium } \\
\text { Good }\end{array}$ & $\begin{array}{l}29 \\
26 \\
3\end{array}$ & $\begin{array}{l}15(51.7) \\
18(69.3) \\
3(100)\end{array}$ & $\begin{array}{l}15(51.7) \\
15(57.7) \\
1(33.3)\end{array}$ & $\begin{array}{l}8(27.6) \\
7(26.9) \\
0(0)\end{array}$ \\
\hline Total & 58 & $36(62)$ & $31(53)$ & $15(25)$ \\
\hline
\end{tabular}

not statistically significant ( $\mathrm{P}=0.856), \mathrm{EHV}-5$ was detected in a lower proportion in horses (24\%; 95\% CI: 0.209-3.669) compared to donkeys (28\%) as shown in Table 5.

EHV-1 was detected at a higher proportion in females (73.1\%; 95\% CI: 0.39-77.86) compared to males (53.1\%), but the difference was not statistically significant $(\mathrm{P}=$ 0.456) as shown in Table 3. Although not statistically significant $(\mathrm{P}=0.317)$, EHV-2 was detected in higher proportion in males $(65.6 \%$; 95\% CI: $3.119-59.816)$ compared to females (38.5\%). Similarly, EHV-5 was detected a higher proportion in males $(28.1 \%$; 95\% CI: 0.179 $3.445)$ compared to females (23.1\%), however, a statistically significant association $(P=0.749)$ was not observed.

In this study, the difference in EHV infection among the different age groups was not statistically significant $(\mathrm{P}$ $>0.05$ ). A higher proportion of EHV-1 was recorded in older equids $(66.7 \%)$ compared to other age groups (Table 3). In contrast, a higher proportion of EHV-2 $(58.3 \%)$ was detected in young equids compared to adults $(52 \%)$ and older age groups (44.4\%) as illustrated in Table 4. Similarly, EHV-5 was detected in a higher proportion in young equids (29.2\%) compared to adults (24\%) and older age groups $(22.2 \%)$ as shown in Table 5.

EHV-1 was recorded in a higher proportion in equids with medium body condition scores $(69.2 \%)$ followed by poor $(51.7 \%)$ and good body condition scores $(100 \%)$. Similarly, EHV-2 was recorded at a higher proportion in equids with medium body condition scores (57.7\%) as compared to good (33.3\%) and poor (51.7\%) body condition scores. EHV-5 was detected in a relatively higher proportion in equids with poor body condition as compared to other body condition scores. However, there was no statistically significant $(\mathrm{P}>0.05)$ difference among the different body condition scores with EHVs positivity.

Table 3 Multivariable Logistic Regression Model for the Association Between Potential Risk Factors with EHV-I Positive Status

\begin{tabular}{|c|c|c|c|c|}
\hline Risk Factors & No. of Equids & EHV-I Positive (\%) & OR (95\% Conf. Interval) & P-value \\
\hline \multicolumn{5}{|l|}{ Species } \\
\hline Horses & 33 & $17(5 \mid .5)$ & $0.29(1.066-2.25 \mathrm{I})$ & $0.047^{*}$ \\
\hline Donkeys & 25 & $19(76)$ & Ref & \\
\hline \multicolumn{5}{|l|}{ Sex } \\
\hline Female & 26 & $19(73.1)$ & $1.77(0.396-77.869)$ & 0.456 \\
\hline Male & 32 & $17(53.1)$ & Ref & \\
\hline \multicolumn{5}{|l|}{ Age } \\
\hline$\geq 10$ years & 9 & $6(66.7)$ & $0.65(0.083-5.026)$ & 0.677 \\
\hline $5-9$ years & 25 & $15(60)$ & $0.82(0.189-3.519)$ & 0.786 \\
\hline$\leq 4$ years & 24 & $15(62.5 \%)$ & Ref & \\
\hline \multicolumn{5}{|c|}{ Body condition score } \\
\hline Good & 3 & $3(100)$ & I & \\
\hline Medium & 26 & $18(69.2)$ & $2.69(0.684-10.559)$ & 0.157 \\
\hline Poor & 29 & $15(5 \mid .7)$ & Ref & \\
\hline
\end{tabular}

Note: *Represent statistically significant.

Abbreviations: Ref, reference; OR, odds ratio. 
Table 4 Multivariable Logistic Regression Model for the Association Between Potential Risk Factors and EHV-2 Positive Status

\begin{tabular}{|c|c|c|c|c|}
\hline Risk Factors & No. of Equids & EHV-2 Positive (\%) & OR (95\% Conf. Interval) & P-value \\
\hline \multicolumn{5}{|l|}{ Species } \\
\hline Donkeys & 25 & $6(24)$ & Ref & \\
\hline Horses & 33 & $25(75.8)$ & $13.66(3.119-59.816)$ & $0.001 *$ \\
\hline \multicolumn{5}{|l|}{ Sex } \\
\hline Male & 32 & $21(65.6)$ & Ref & \\
\hline Female & 26 & $10(38.5)$ & $0.48(7.192-41.163)$ & 0.317 \\
\hline \multicolumn{5}{|l|}{ Age } \\
\hline$\leq 4$ years & 24 & $14(58.3)$ & Ref & \\
\hline 5-9 years & 25 & $13(52)$ & $\mathrm{I} .07(0.247-4.6 \mathrm{II})$ & 0.929 \\
\hline$\geq 10$ years & 9 & $4(44.4)$ & I.I8 (0.162-8.395) & 0.877 \\
\hline \multicolumn{5}{|c|}{ Body condition score } \\
\hline Poor & 29 & $15(51.7)$ & Ref & \\
\hline Medium & 26 & $15(57.7)$ & $1.36(0.339-5.417)$ & 0.667 \\
\hline Good & 3 & I (33.3) & $0.078(0.003-1.951)$ & 0.120 \\
\hline
\end{tabular}

Note: *Represent statistically significant.

Abbreviations: Ref, reference; OR, odds ratio.

Table 5 Multivariable Logistic Regression Model for the Association Between Potential Risk Factors and EHV-5 Positive Status

\begin{tabular}{|c|c|c|c|c|}
\hline Risk Factors & No. of Equids & EHV-5 Positive (\%) & OR (95\% Conf. Interval) & P-value \\
\hline \multicolumn{5}{|l|}{ Species } \\
\hline Donkeys & 25 & $7(28)$ & Ref & \\
\hline Horses & 33 & $8(24.3)$ & $0.88(0.209-3.669)$ & 0.856 \\
\hline \multicolumn{5}{|l|}{ Sex } \\
\hline Male & 32 & $9(28.2)$ & Ref & \\
\hline Female & 26 & $6(23.1)$ & $0.79(0.179-3.445)$ & 0.749 \\
\hline \multicolumn{5}{|l|}{ Age } \\
\hline$\leq$ 4years & 24 & $7(29.2)$ & Ref & \\
\hline $5-9$ years & 25 & $6(24)$ & 0.91 (0.219-3.783) & 0.899 \\
\hline$\geq 10$ years & 9 & $2(22.2)$ & $0.66(0.089-4.939)$ & 0.689 \\
\hline \multicolumn{5}{|c|}{ Body condition score } \\
\hline Poor & 29 & $8(27.6)$ & Ref & \\
\hline Medium & 26 & $7(26.9)$ & $0.92(0.249-3.425)$ & 0.906 \\
\hline Good & 3 & $0(0)$ & & \\
\hline
\end{tabular}

Abbreviations: Ref, reference; OR, odds ratio.

\section{Discussion}

In the present study, EHV-1, -2, and -5 were identified from clinically respiratory diseased equids. A high proportion of equids $(77.6 \%)$ in the present study was positive for more than one type of EHVs. This might be associated with either reactivation of the latent equine herpesvirus or primary infection. In the present study, mixed infections with EHV-1 and EHV-2 (31\%), EHV-1 and EHV-5 (17\%), EHV-2 and EHV-5 (15.5\%), and EHV-1, -2, and -5 $(13.8 \%)$ were recorded. Although co-infection of EHVs was detected from equids with suggestive clinical signs of respiratory disease, their synergistic effect on the clinical outcomes remains unknown.

Analysis of the results obtained from EHVs cases outlines that EHV-1 is the most prevalent type detected, with an overall percentage of $62 \%$. This correlates with other studies done in Egypt (64\%) ${ }^{24}$ and the Republic of Serbia $(59.1 \%),{ }^{25}$ but relatively higher than the findings in Ethiopia $(7.5 \%)^{18}$ and Algeria $(2 \%){ }^{26}$ In the current study, identification of EHV-2 in 53\% equids with signs 
of respiratory disease is relatively higher than other studies reported around the world. In previous studies, EHV-2 was identified in $20 \%$ of equids with signs of acute upper respiratory disease in Ethiopia ${ }^{18}$ and $19.2 \%$ of equids in Turkey. $^{27}$ Similarly, EHV-5 was detected in $25 \%$ of respiratory diseased equids in the present study. This is consistent with a report from Turkey $(21.9 \%)^{27}$ and Ethiopia (23.1\%), ${ }^{18}$ but considerably higher than reported in New Zealand $(71 \%)^{28}$ and France $(63.4 \%){ }^{29}$ EHVs might directly cause respiratory illness or predispose to other opportunistic pathogens. There has been unequivocal evidence that EHV-1 is the major cause of respiratory disease in equids globally. However, in the previous studies, EHV-2 and -5 were detected from immunocompetent equids without signs of respiratory disease..$^{9,30,31}$ Thus, our results support the notion that EHV-2 and/or EHV-5 in equids may either compromise the host immunity and increase susceptibility to opportunistic infections ${ }^{8,32}$ or play a direct role in the development of respiratory disease in equids.

In the present study, the proportion of equids positive for EHVs varied with the species of equids. Donkeys had 0.26 times (OR: 0.26; 95\% CI: 1.066-2.251; $\mathrm{P}=0.047$ ) more likely to be positive for EHV-1 compared to horses. This is comparable to the results of a recent study done by Negussie et $\mathrm{al}^{18}$ who reported that a larger proportion of donkeys were positive for EHV-1 than horses. The higher EHV-1 infections in Ethiopian donkeys might be linked with the genetic susceptibility of the host and/or immunosuppression associated with stress-related to heavy workload, long-distance travel, and poor nutritional status in the donkeys. Long-distance transport can increase the risk of respiratory disease as a consequence of immunosuppression and stress-associated viral reactivation. ${ }^{33}$ In contrast, horses had fourteen times more likely to be positive for EHV-2 (OR: 13.66; 95\% CI: 3.119-59.816; $\mathrm{P}=0.001$ ) compared to donkeys. This is in agreement with previous studies where EHV-2 and EHV-5 were predominantly found in horses. ${ }^{34-36}$ At present, a possible explanation of why donkeys and horses have varying susceptibility to EHV infection could not be given. More work is needed to elucidate the exact relationships between host susceptibility to EHVs positivity.

In the present study, the proportion of EHVs positive equids varied for different age groups. In the current study, a high proportion of EHV-1 was detected among adults. This is in agreement with a recent report from Ethiopia ${ }^{18}$ and Algeria ${ }^{26}$ where EHV-1 was most commonly detected among adults. The possible explanation is that working equids are exposed to a heavy workload during the adult age, which subsequently results in reactivation of the latent virus, but this requires further investigation. In contrast, EHV-2 and EHV-5 were detected in a higher proportion among young equids. In agreement with our results, EHV-2 and -5 were the most common infections detected from the respiratory tract of young horses. ${ }^{26,28,37}$ Young foals might be exposed to EHV-2 and -5 infection from the mares during the first months, after which the virus is also spread horizontally to their contact foals, as has been suggested by others. ${ }^{29,38,39}$

\section{Conclusions}

The present study revealed the molecular evidence of EHV-1, -2, and -5 infection in donkeys and horses with signs of respiratory disease. Concurrent infection with EHV-1 and EHV-2, EHV-1 and EHV-5, EHV-2 and EHV-5, and EHV-1, -2, and -5 were recorded. It also documented that donkeys and horses have varying levels of susceptibility to EHVs. This species-specific difference in susceptibility to EHVs infections should be further elucidated.

\section{Ethical Consideration}

Ethical approval for this study was granted from the animal research ethical review committee of the College of Veterinary Medicine and Agriculture of the Addis Ababa University (Reference number: VM/ERC/08/01/12/2020). All methods were performed in accordance with relevant guidelines and regulations. All protocols were approved by the animal research ethical review committee. Before conducting the research, equine owners were informed with the objectives and the benefits of the study, and they gave consent for their animal's inclusion in the study. Equine owners gave verbal consent for their animal's inclusion in the study because they are unable to write and read. These consents were taken in the presence of a third independent party.

\section{Acknowledgments}

The authors would like to acknowledge the National Veterinary Institute (NVI) of Ethiopia for the provision of laboratory facilities. We also acknowledge the equine owners for their willingness and commitment to support the success of this research work. 


\section{Funding}

This study was supported by the Addis Ababa University thematic research fund (VPRTT/PY-096/2018), Ethiopia. The funder had no role in the conception, design of the study, data collection, analysis, and interpretation of the data reported in this manuscript.

\section{Disclosure}

The authors declare that they have no competing interests in this work.

\section{References}

1. Stringer A, Lunn DP, Reid S. Science in brief: report on the first $\mathrm{H}$ Havemeyer workshop on infectious diseases in working equids, Addis Ababa, Ethiopia, November 2013. Equine Vet J. 2015;47 (1):6-9. doi:10.1111/evj.12359

2. Allen GP, Murray MJ. Equid herpesvirus 2 and equid herpesvirus 5 infections. In: Coetzer J, Tustin R, editors. Infectious Diseases of Livestocks; 2004: 860-867.

3. Lunn DP, Davis-Poynter N, Flaminio M, et al. Equine herpesvirus-1 consensus statement. $J$ Vet Intern Med. 2009;23(3):450-461. doi:10.1111/j.1939-1676.2009.0304.x

4. Laing G, Christley R, Stringer A, et al. Unraveling the causes of respiratory disease in the working equids of Ethiopia: a cross sectional survey. J Equine Vet Sci. 2016;39:s98-s107. doi:10.1016/j. jevs.2016.02.209

5. Allen GP, Kydd JH, Slater JD, Smith KC. Equid herpesvirus 1 and equid herpesvirus 4 infections. In: Coetzer JAW, Tustin RC, editors. Infectious Diseases of Livestock. Oxford Press; 2004:829-859.

6. Schulman M. The impact of herpesviruses on reproductive performance in horses [Thesis]. Universiteit Utrecht; 2016:78-94.

7. Easton C, Fuentealba NA, Paullier C, Alonzo P, Carluccio J, Galosi CM. Immunohistochemical and molecular detection of equine herpesvirus 1 in Uruguay. Rev Sci Tech. 2009;28(3):1085-1090. doi:10.20506/rst.28.3.1957

8. Dunowska M, Wilks CR, Studdert MJ, Meers J. Equine respiratory viruses in foals in New Zealand. N Z Vet J. 2002;50(4):140-147. doi: $10.1080 / 00480169.2002 .36300$

9. Wang L, Raidal SL, Pizzirani A, Wilcox GE. Detection of respiratory herpesviruses in foals and adult horses determined by nested multiplex PCR. Vet Microbiol. 2007;121(1-2):18-28. doi:10.1016/j. vetmic.2006.11.009

10. Rushton JO, Kolodziejek J, Nell B, Weissenböck H, Nowotny N. Keratoconjunctivitis in a group of Icelandic horses with suspected gammaherpesvirus involvement. Equine Vet J. 2016;48(4):427-429. doi:10.1111/evj.12465

11. Rushton JO, Kolodziejek J, Tichy A, Nell B, Nowotny N. Detection of equid herpesviruses 2 and 5 in a herd of 266 Lipizzaners in association with ocular findings. Vet Microbiol. 2013;164(12):139-144. doi:10.1016/j.vetmic.2013.01.035

12. Williams KJ, Maes R, Del Piero F, et al. Equine multinodular pulmonary fibrosis: a newly recognized herpesvirus-associated fibrotic lung disease. Vet Pathol. 2007;44(6):849-862. doi:10.1354/vp.446-849

13. Dunowska M, Hardcastle MR, Tonkin FB. Identification of the first New Zealand case of equine multinodular pulmonary fibrosis. $N Z$ Vet J. 2014;62(4):226-231. doi:10.1080/00480169.2014.899933

14. Edington N. Latency of equine herpesviruses. Proceedings of the Sixth International Conference on Equine Infectious Diseases. Cambridge: R\&W Publications, Newmarket; 1992:195-200.
15. Hussey GS, Landolt GA. Equine Alphaherpesviruses. In: Robinson's Current Therapy in Equine Medicine. 7th ed. Elsevier Inc; 2015:158-161.

16. Slater J. Equine Herpesviruses. In: Equine Infectious Diseases. 2nd ed. Elsevier Inc.; 2014:151-168.

17. Negussie H, Gizaw D, Tessema TS, Nauwynck HJ. Equine Herpesvirus-1 myeloencephalopathy, an emerging threat of working equids in Ethiopia. Transbound Emerg Dis. 2017;64(2):389-397. doi:10.1111/tbed.12377

18. Negussie H, Gizaw D, Tesfaw L, et al. Detection of Equine Herpesvirus (EHV) $-1,-2,-4$ and -5 in Ethiopian Equids with and without respiratory problems and genetic characterization of EHV-2 and EHV-5 strains. Transbound Emerg Dis. 2017;64(6):1970-1978. doi:10.1111/tbed.12601

19. Cozzi B, Ballarin C, Mantovani R, Rota A. Aging and veterinary care of cats, dogs, and horses through the records of three university veterinary hospitals. Front Vet Sci. 2017;4:1-11. doi:10.3389/fvets.2017.00014

20. Henneke D, Potter GD, Kreider JL, Yeates BF. Relationship between condition score, physical measurements and body fat percentage in mares. Equine Vet J. 1983;15(4):371-372. doi:10.1111/j.20423306.1983.tb01826.x

21. Goodman LB, Loregian A, Perkins GA, et al. A point mutation in a herpesvirus polymerase determines neuropathogenicity. PLoS Pathog. 2007;3(11):1583-1592. doi:10.1371/journal.ppat.0030160

22. Diallo I, Hewitson GR, Jong A, et al. Equine herpesvirus infections in yearlings in South-East Queensland. Arch Virol. 2008;153 (9):1643-1649. doi:10.1007/s00705-008-0158-y

23. Holloway SA, Lindquester GJ, Studdert MJ, Drummer HE. Identification, sequence analysis and characterisation of equine herpesvirus 5 glycoprotein B. Arch Virol. 1999;144(2):287-307. doi:10.1007/s007050050504

24. Ata EB, Salama A, Zaghawa A, et al. Seroprevalence of equine herpes virus-1 in endemic area of Egypt with risk factors assessment. Bulg J Vet Med. 2020;23(1):102-111. doi:10.15547/bjvm.2168

25. Radalj A, Nišavić J, Krnjaić D, et al. Detection and molecular characterization of equine herpesviruses 1,2, and 5 in horses in the Republic of Serbia. Acta Vet Brno. 2018;87(1):27-34. doi:10.2754/ avb201887010027

26. Laabassi F, Hue E, Fortier C, et al. Epidemiology and molecular detection of equine herpesviruses in western Algeria in 2011. Vet Microbiol. 2017;207:205-209. doi:10.1016/j.vetmic.2017.06.017

27. Ataseven VS, Bilge-Dagalp S, Oguzoglu TC, Karapinar Z, Guzel M, Tan MT. Detection and sequence analysis of equine gammaherpesviruses from horses with respiratory tract disease in Turkey. Transbound Emerg Dis. 2010;57(4):271-276. doi:10.1111/j.18651682.2010.01146.x

28. Mcbrearty KA, Murray A, Dunowska M. A survey of respiratory viruses in New Zealand horses. N Z Vet J. 2013;61(5):254-261. doi:10.1080/00480169.2012.745211

29. Hue ES, Fortier GD, Fortier CI, et al. Detection and quantitation of equid gammaherpesviruses (EHV-2, EHV-5) in nasal swabs using an accredited standardized quantitative PCR method. J Virol Methods. 2014;198:18-25. doi:10.1016/j.jviromet.2013.12.008

30. Bell SA, Balasuriya UB, Nordhausen RW, MacLachlan NJ. Isolation of equine herpesvirus-5 from blood mononuclear cells of a gelding. $J$ Vet Diagn Invest. 2006;18(5):472-475. doi:10.1177/104063 870601800509

31. Torfason EG, Thorsteinsdóttir L, Torsteinsdóttir ST, Svansson VS. Study of equid herpesviruses 2 and 5 in Iceland with a type-specific polymerase chain reaction. Res Vet Sci. 2008;85(3):605-611. doi:10.1016/j.rvsc.2008.01.003

32. Nordengrahn A, Rusvai M, Merza M, Ekstrom J, Morein B, Belak S. Equine herpesvirus type 2 (EHV-2) as a predisposing factor for Rhodococcus equi pneumonia in foals: prevention of the bifactorial disease with EHV-2 immunostimulating complexes. Vet Microbiol. 1996;51(1-2):55-68. doi:10.1016/0378-1135(96)00032-6 
33. Muscat KE, Padalino B, Hartley CA, et al. Equine transport and changes in Equid Herpesvirus' status. Front Vet Sci. 2018;5:1-10. doi:10.3389/fvets.2018.00224

34. Franchini M, Akens M, Bracher V, von Fellenberg R. Characterisation of gammaherpesviruses in the horse by PCR Virology. 1997;238(1):8-13. doi:10.1006/viro.1997.8825

35. Craig MI, Barrandeguy ME, Fernández FM. Equine herpesvirus 2 (EHV-2) infection in thoroughbred horses in Argentina. BMC Vet Res. 2005;1(1):9. doi:10.1186/1746-6148-1-9

36. Goehring LS. Equid herpesvirus-Associated myeloencephalopathy. In: Robinson's Current Therapy in Equine Medicine. 7th ed. Elsevier Inc; 2015:387-390.
37. Stasiak K, Dunowska M, Rola J. Prevalence and sequence analysis of equid herpesviruses from the respiratory tract of Polish horses. Virol J. 2018;15(1):1-13. doi:10.1186/s12985-018-1018-3

38. Bell SA, Balasuriya UBR, Gardner IA, et al. Temporal detection of equine herpesvirus infections of a cohort of mares and their foals. Vet Microbiol. 2006;116(4):249-257. doi:10.1016/j.vetmic.2006.05.002

39. Brault SA, Bird BH, Balasuriya UBR, MacLachlan NJ. Genetic heterogeneity and variation in viral load during equid herpesvirus-2 infection of foals. Vet Microbiol. 2011;147(3-4):253-261. doi:10.1016/j.vetmic.2010.06.031

Veterinary Medicine: Research and Reports

\section{Publish your work in this journal}

Veterinary Medicine: Research and Reports is an international, peerreviewed, open access journal publishing original research, case reports, editorials, reviews and commentaries on all areas of veterinary medicine. The manuscript management system is completely online and includes a very quick and fair peer-review system. Visit http://www.dovepress.com/testimonials.php to read real quotes from published authors.

Submit your manuscript here: http://www.dovepress.com/veterinary-medicine-research-and-reports-journal 